\title{
The 2019 European Parliament Elections in Luxembourg in the Context of Past Elections
}

Anna-Lena Högenauer (University of Luxembourg)

Working Paper: 2019

\begin{abstract}
The aim of this article is to analyse the 2019 European election in Luxembourg and to contextualize it by comparing it with past elections. The article presents the party landscape, the electoral campaign, the electoral system and the results of the 2019 European election. The results are then analysed in the context of past national and European elections in order to establish whether European elections are second-order elections in Luxembourg, how electoral volatility evolved over time, whether there is a rise in Eurosceptic parties and how the representation of women has evolved since 1979.
\end{abstract}

Keywords: European Parliament, election, Luxembourg, second-order election, Spitzenkandidat, euroscepticism

\section{Overview of the Political Landscape}

The Grand Duchy of Luxembourg is a constitutional monarchy with a parliamentary democratic regime. Legislation can be initiated by the parliament (the Chambre des Députés) or by the government. The parliament has to approve legislation. Until 2009, the signature of the Grand Duke was required to approve bills, but a revision of article 34 of the Constitution abolished this requirement after a disagreement over the Grand Duke's refusal to sign a law on euthanasia (Dumont, Kies and Poirier 2016).

As a small country, Luxembourg has a unicameral parliamentary system, but the Council of State has to comment on every law before the vote in parliament. This arrangement is designed to stimulate debate and introduce another perspective in the legislative process. Finally, the activity of the government and parliament is also checked by a Constitutional Court, a Court of Auditors and an Ombudsman. These institutions are comparatively recent, having been created between 1996 and 2004. 
Table 1: Country Profile Luxembourg

\begin{tabular}{|l|l|}
\hline EU Entry Year & $\begin{array}{l}1952 \text { European Coal and Steel Community } \\
1957 \text { European Economic Community and Euratom }\end{array}$ \\
\hline MEPs in 2019 & 6 \\
\hline MEPs after Brexit & 6 \\
\hline Capital & Luxembourg \\
\hline Total Area* (including inland waters) in km2 & 2,586 \\
\hline Population on 1 January 2019 (x1000) & Total: 613.9 \\
\hline Population in terms of nationalities on 1 January & Luxembourger: 52.52\% \\
2019 & Portuguese: $15.56 \%$ \\
& French: 7.65\% \\
Italy: 3.66\%
\end{tabular}

Based on STATEC data for 2019 (https://statistiques.public.lu/en/index.html)

In the European context, the country stands out through its small size of around 600,000 residents, which makes it the second-smallest member state. In addition, it is the EU member state with the highest proportion of foreign residents. Due to sustained immigration from other European states since the early $20^{\text {th }}$ century, the proportion of foreign residents grew rapidly and has now reached over 47 percent. Democratically, this is a challenge as almost half the population does not have the right to vote in national elections. European citizens can participate in European elections now (a five-year residency requirement was recently lifted) and foreign residents can participate in local elections.

In light of the small size, the high proportion of foreign residents and the presence of a number of European institutions, it is interesting to analyse whether Luxembourg experiences the same trends as the EU in general.

\section{The Political Parties}

Luxembourg's political landscape was dominated by the Christian Democrats (CSV Chrëschtlech Sozial Vollekspartei), a member of the European People's Party, most of the time since the Second World War. The party was almost continuously in government, except for a brief period from 1974 to 1979 . It has been in opposition since the 2013 legislative elections, however, and lost further votes at the 2018 legislative elections. It currently has around 10,000 members (https://csv.lu/eis-partei/presentatioun-partei/). The party is inspired by a social Catholic doctrine that allowed it to position itself on a liberal conservative cleavage. Socially, its catholic conservatism allowed it to appeal to the rural areas of the country, but also to the mainly Catholic migrants. Meanwhile, its social doctrine allowed it to develop a catholic trade union, to adopt a centrist position on the economic cleavage and to develop also working-class support (cf. Dumont, Kies, and Poirier 2016). Its long periods in government have allowed it to build up a strong support basis among civil servants. 
While the CSV is still the biggest party in parliament, the government is currently formed by the second largest party (DP - Demokratesch Partei, Democratic Party), the third largest party (LSAP - Lëtzebuerger Sozialistesch Arbechterpartei, Luxembourgish Socialist Workers' Party) and the fourth largest party (Déi Gréng, the Greens). The DP is part of Reform Europe, the LSAP of the Progressive Alliance of Socialists and Democrats and the Greens of the Greens/European Free Alliance. The LSAP is a social democrat party that aims to represent the working class, even though its ties to the trade unions have weakened over time. It used to be particularly strong in local elections (Dumont, Kies and Poirier 2016), but has recently experienced electoral decline and losses in traditional strongholds in the South in the 2017 local elections. It used to be in government as the CSV's junior partner during much of the period since the Second World War. It has around 5,000 members.

The DP is a liberal party that advocates minimal state intervention in the economy, the protection of businesses, but also of liberal social values. It is currently the second largest party at the national level and has even become the largest party in the last European elections. The Greens were founded in 1983 out of social movements, and have recently gained strong electoral support, becoming the fourth largest party in the country with around 15 percent electoral support. Apart from its focus on environmental issue, the party adopts a socially liberal approach and a centrist economic approach.

Aside from those four players a number of smaller parties exist. The Alternative Democratic Reform Party (ADR - Alternativ Democratesch Reformpartei) was originally founded in 1987 under another name as a single issue protest party with a focus on pensions. Nowadays the party defines itself as a conservative alternative to the established parties. Ideologically it is values Catholicism and conservative values. The party has undergone several transformations in its young history, and it has recently moved towards more right-wing and restrictive positions on migration and an emphasis on the protection and promotion of the Luxembourgish language. A new right-wing party, Déi Konservativ (the Conservatives) participated in the most recent elections. It adopts nationalist and strong anti-immigration positions, but has so far only attracted about half a percent of support.

On the left, Déi Lenk (The Left) and the Communist Party compete for voters. The Communist Party experienced electoral decline in the early 1990s and has not recovered since. The Left has achieved some success in national elections, and gathers trade unionists, socialists and Trotskyites.

Finally, the Pirates (founded in 2009) took part in the last two round of national and European elections and entered the national parliament in 2018. They focus on data protection, access to education, grass-root democracy and equal opportunities. 
Figure 1: Luxembourgish Parties on the Left-Right Spectrum

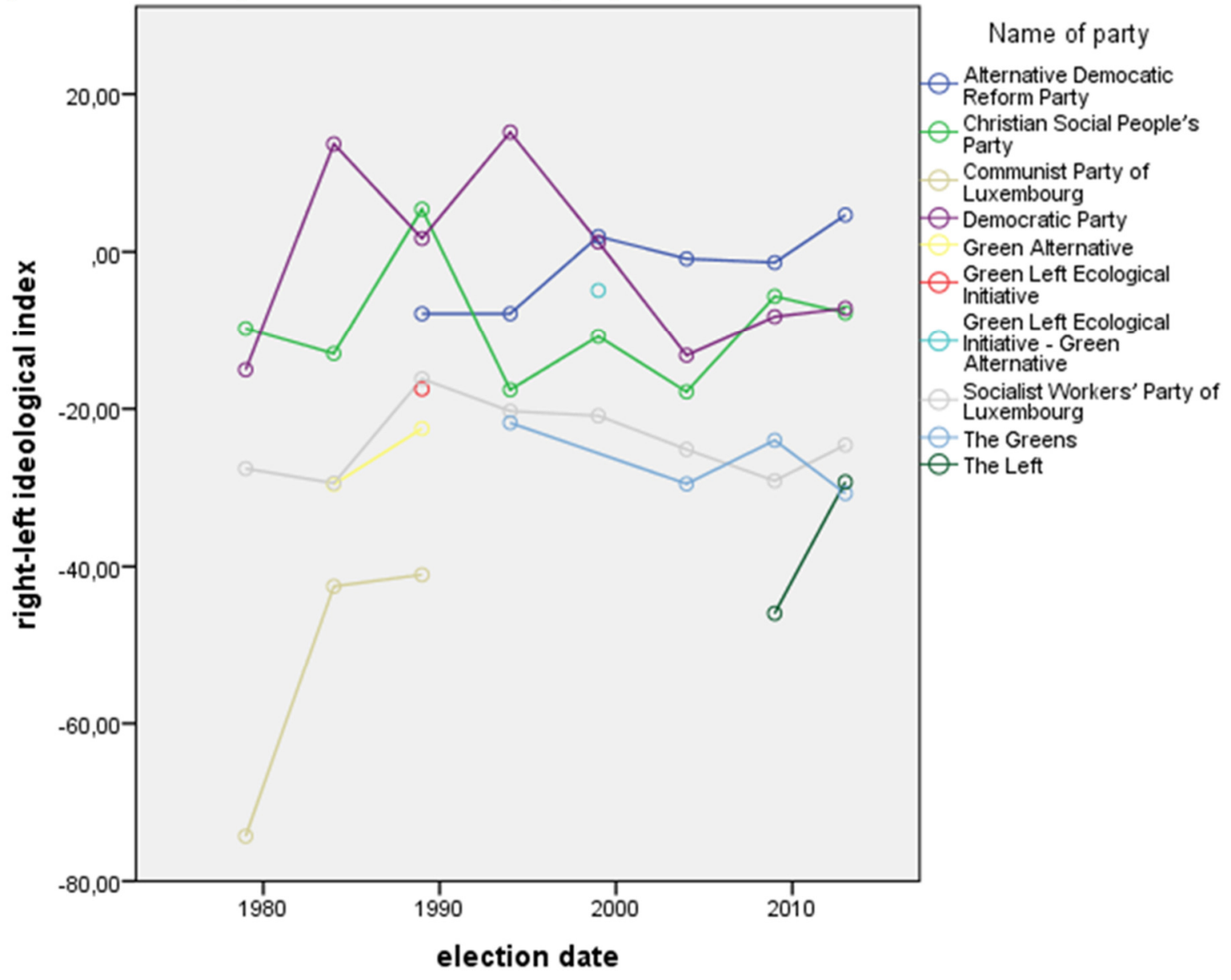

Volkens, Andrea / Krause, Werner / Lehmann, Pola / Matthieß, Theres / Merz, Nicolas / Regel, Sven / Weßels, Bernhard (2018): The Manifesto Data Collection. Manifesto Project (MRG/CMP/MARPOR). Version 2018b. Berlin: Wissenschaftszentrum Berlin für Sozialforschung (WZB).

https://doi.org/10.25522/manifesto.mpds.2018b

A negative score denotes a more left-wing position. A positive score a more right-wing position.

Despite the fact that elections are now contested by a number of different parties, the parties all occupy a relatively small space on the left-right spectrum. A study of Luxembourgish parties until 2013 by Volkens et al. (2018) shows that almost all Luxembourgish parties are slightly left leaning. In 2013, only the ADR was somewhat to the right of the centre, while the CSV and the DP were very centrist and the LSAP, déi Gréng and déi Lénk were somewhat left-leaning. However, one should note that the new right-wing déi Konservativ and the Pirates were not yet part of the study.

\subsection{Party Attitude towards the European Union}

Most parties are in principle pro-European and support further integration. Traditionally the most pro-European party was the CSV, which is internally cohesive in this respect. However, if the Luxembourgish parties are only classified as fairly moderately pro-European (cf. Figure 2 ), this is also due to the fact that Luxembourgish politicians have the tendency to occasionally defend national priorities. Historically, this includes the interests of the steel industry during the foundation of the European Coal and Steel Community, protectionism towards the farming 
sector in the context of the Common Agricultural Policy or, currently, the defence of the financial sector and the Luxembourgish approach to taxation.

However, nowadays the four main parties are so close together, that there is no real competition on this dimension. As a result, the salience of European issues in domestic elections is low, and even in European elections there is not much of a cleavage.

On the margins, déi Lénk and the ADR criticize EU integration, but only in terms of the need to correct mistakes, not in terms of questioning its existence or Luxembourg's EU membership. Both parties recognize that Luxembourg depends on the EU economically. The only two parties that genuinely question the EU are the Communist Party that objects to the perceived liberalism of the internal market. It advocates a relaunch of a new European project with more grass-roots democracy. In addition, the Conservatives oppose the EU and want a Europe of Nation states. However, those two parties together have less than 2 percent of the vote. There are also no ambitions to leave the Euro, as Luxembourg did not have an independent currency before the introduction of the euro. Before Economic and Monetary Union, the Luxembourgish Franc was tied to the Belgian Franc, and Luxembourg had virtually no control over currency-related decisions.

Figure 2: Luxembourgish Parties and European Integration

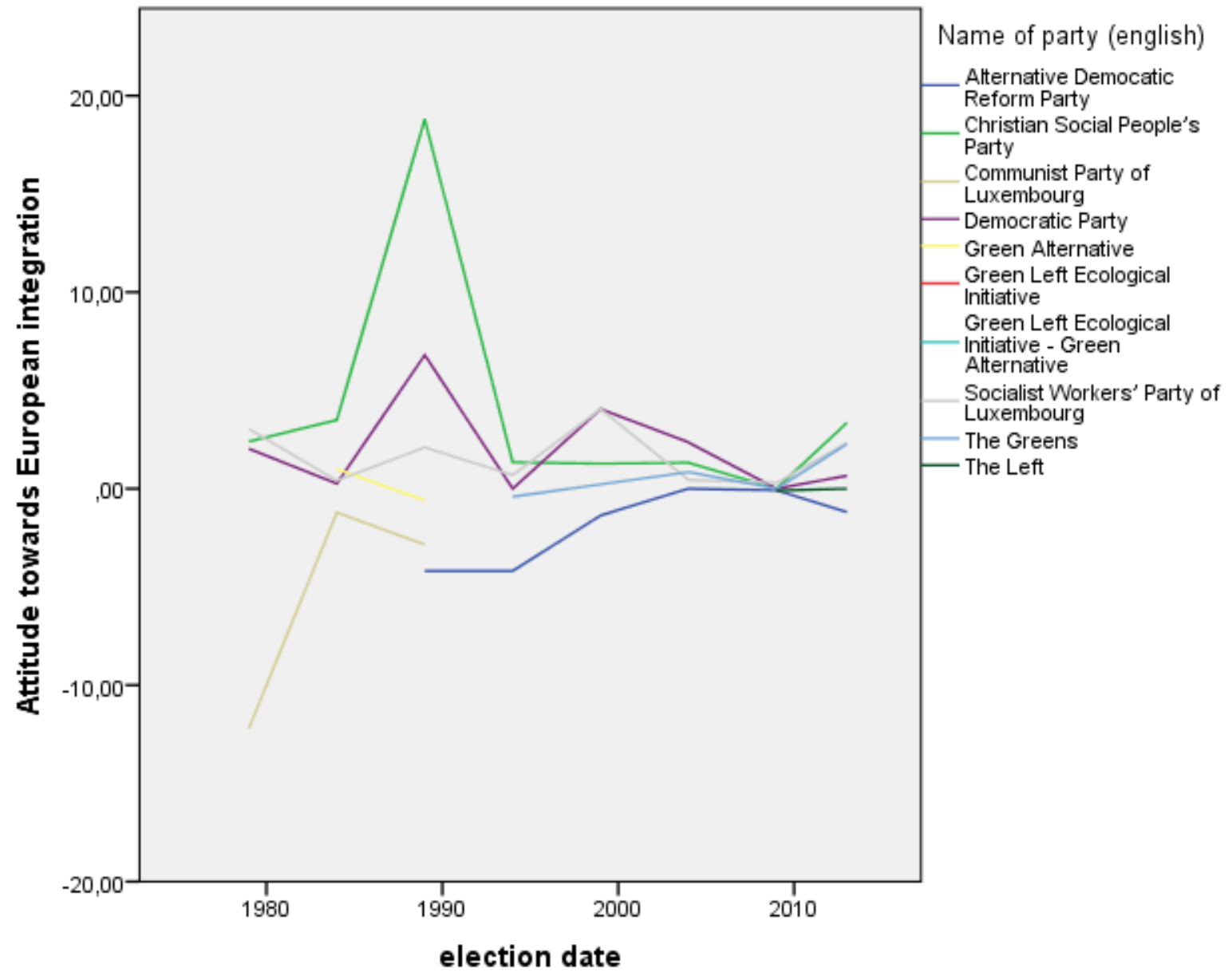

Volkens, Andrea / Krause, Werner / Lehmann, Pola / Matthieß, Theres / Merz, Nicolas / Regel, Sven / Weßels, Bernhard (2018): The Manifesto Data Collection. Manifesto Project (MRG/CMP/MARPOR). Version 2018 b. 
Berlin: Wissenschaftszentrum Berlin für Sozialforschung (WZB).

https://doi.org/10.25522/manifesto.mpds.2018b

\subsection{Public Opinion and the European Union}

Luxembourg is one of the most pro-European countries in the European Union today. It is no coincidence that most parties are broadly pro-European. A large majority of citizens support EU membership and usually around 80-90 percent of Luxembourgers state in Eurobarometer surveys that they think of themselves as EU citizens (e.g. 89 percent in Eurobarometer 90 of autumn 2018). In addition, there is wide-spread support for common policy-making in a range of areas. Recent Eurobarometer surveys show, for example, that support for an economic and monetary union, the free movement of citizens, a common energy policy, a common security and defence policy and a common migration policy ranges from 80 to 90 percent (Eurobarometer 89, 90 2018). Historically, support for EU membership has generally been high since 1979. In 1979, 83 percent supported EU membership. This fell to 80 percent in 1984, 77 percent in 1989 and to 71 percent in 1994 . However, support then started to rise again and reached 75 percent in 2004 and 79 percent in 2009 (Eurobarometer surveys 22, 22, 31, 41, 51, 61 and 71).

As Harmsen and Högenauer (2019) show, Luxembourgers are somewhat less enthusiastic about the functioning of the EU: Only 65 percent are satisfied with the functioning of the EU. 56 percent of people have a positive image of the EU and trust in the European Parliament and the European Commission is at 55 to 60 percent (Eurobarometer 90). Support for the European Union has recovered since the Eurozone crisis, though. Only 40 percent of Luxembourgers had a positive image of the EU in 2013 (Eurobarometer 80). Also, one area where Luxembourgers remain unconvinced is enlargement. In autumn 2018, 55 percent of them opposed further enlargements of the European Union (Eurobarometer 90).

\section{The Electoral System}

The six Luxembourgish MEPs are elected by direct universal suffrage, in a system that is closely based on the system used in national elections. The main difference is that the country is treated as a single constituency due to the small number of MEPs, whereas in national elections MPs are elected in four constituencies (Centre, North, East and South). For both national and European elections a proportional representation system with open party lists is used. A majority of candidates on the lists for the European elections has to have the Luxembourgish nationality.

In the case of the European elections, the voters can choose between two approaches: they can either cast a vote for a party list, or they can vote for individual candidates. If a voter decides to vote for candidates rather than a party, he or she can cast as many votes as there are seats (i.e. six in the case of the EP elections). Voters are allowed to support candidates from different parties, and they can give up to two votes to their preferred candidates. In the case of national elections, voters who wish to vote for individual candidates have as many votes as there are MPs from their constituency. 
In the end, the total number of votes for a party (i.e. list votes plus votes for individual candidates) determines the distribution of seats. The ranking of candidates based on votes will determine who wins those seats. The ranking of candidates on the party lists is strictly alphabetically. In other words, there are no easily identifiable 'lead candidates' on the ballot itself, and the voters - not the party - determine who among the candidates will enter parliament. This distinguishes the Luxembourgish system from other proportional list systems, where candidates are usually listed strategically based on a decision by the party. Luxembourgish voters make active use of the 'open' nature of the lists, with around 40-50 percent of voters opting to vote for candidates rather than lists (Dumont et al. 2011; Schmit 2018).

Another distinguishing feature is that voting is mandatory. All registered voters have the duty to vote unless they are over 75 years of age or reside in a commune other than the one where they are registered. Other voters who fail to take part in the election have to justify their absence to the local State Prosecutor and produce supporting documentation, otherwise they risk a incurring a fine. Postal voting is possible. Luxembourgish nationals receive the right to vote at the age of 18. European citizens residing in Luxembourg are also allowed to vote, but have to register for the electoral list first. Once they have registered, voting is also mandatory for European citizens.

One important reform was the decision to reduce the size of the party lists for European elections from twelve candidates to six candidates per party in 2008. The option to have up to twelve candidates on the list led to parties putting prominent national politicians on both lists for the national and the European election, which took place at the same time until 2009. They would attract a lot of personal votes, and often did not take up their seat in the EP because they obtained a government position in Luxembourg. As a result, it was not uncommon that a large proportion of Luxembourgish MEPs would be replacements. The section on gender (below) illustrates this further. By reducing the lists to six candidates, the 2008 reform encouraged the parties to concentrate on 'serious' candidates. According to Dumont, Kies and Poirier (2016), the larger parties in addition voluntarily agreed to end the practice of putting candidates on both national and European lists (in 2004 58/60 candidates for the European election also ran for the national election).

\section{The 2019 European Election: Empirical Analysis}

\subsection{The Campaign}

\subsubsection{Lists}

Ten parties participated in the 2019 European election, two of them for the first time. 
Table 2: Lists

\begin{tabular}{|l|l|l|l|}
\hline & No. candidates & No. Female candidates & \%female candidates \\
\hline CSV & $\mathbf{6}$ & $\mathbf{3}$ & $\mathbf{5 0}$ \\
\hline LSAP & $\mathbf{6}$ & $\mathbf{3}$ & $\mathbf{5 0}$ \\
\hline DP & $\mathbf{6}$ & $\mathbf{3}$ & $\mathbf{5 0}$ \\
\hline Déi Gréng & $\mathbf{6}$ & $\mathbf{3}$ & $\mathbf{5 0}$ \\
\hline ADR & $\mathbf{6}$ & $\mathbf{3}$ & $\mathbf{5 0}$ \\
\hline KPL & $\mathbf{6}$ & $\mathbf{3}$ & $\mathbf{5 0}$ \\
\hline Déi Lénk & $\mathbf{6}$ & $\mathbf{3}$ & $\mathbf{5 0}$ \\
\hline Volt Europa & $\mathbf{6}$ & $\mathbf{3}$ & $\mathbf{5 0}$ \\
\hline Piraten & $\mathbf{6}$ & $\mathbf{2}$ & $\mathbf{3 3 . 3 3}$ \\
\hline Déi Konservativ & $\mathbf{6}$ & $\mathbf{2}$ & $\mathbf{3 3 . 3 3}$ \\
\hline
\end{tabular}

\subsubsection{Party Manifestos}

The CSV presented a very text-heavy programme where no clear priorities stood out. Under the heading of a 'social and progressive Europe', it opposed geo-blocking by companies and advocated hydrogen-based energy solutions, more medical research and research into artificial intelligence, including its ethical aspects, and a new course for children on European integration. As part of a 'safe and just Europe' it demanded better police cooperation across member states, that migrants have to respect our constitutional norms and that payments from the structural fonds to member states are tied to the respect for the state of law. It also proposed the taxation of internet companies and higher tariffs on agricultural imports that could be produced locally. Finally, under a 'strong Europe in the world' it proposed to increase the EU's budget through a tax on $\mathrm{CO}^{2}$ products and to insist on reciprocity with regard to market access.

The DP demanded a stronger foreign and development policy, more sustainable free trade agreements that guarantee high social and economic standards and fewer weapons in the world. It proposed the automatic recognition of diplomas from EU member states, more financial support for the Erasmus programme, a 'youth guarantee' that provides young people with a job, an internship or a training programme and an extension of free rail travel for young people to discover Europe. The EU should make the fight against climate change a priority, ensure the use of more renewable energies, implement a common migration policy that protects the external borders and distributes refugees across member states and the possibility of class act law suits to protect consumers better. The DP also supported sustainable infrastructural projects, the 5-G network and a digital internal market without geoblocking. Finally, it opposed further enlargement until all member states respect the common European values, wanted to introduce a sanction mechanism for states that depart from those values and proposed European-wide social minimum standards.

Under the slogan 'Europe. Clearly. Different.', the LSAP also presented a long list of suggestions, but some core themes (e.g. the environment, digitalisation) stood out. Most notably, it wanted to strengthen gender equality, introduce a European minimum wage, improve the co-decision rights of workers and introduce a European agency for employment that fights social dumping. It also wanted to give consumers the right to launch class action law suits. It played up the environmental dimension and demanded a better labelling of food, an EU sustainability passport for companies to regulate access to the internal market, social and ecological criteria for public procurement and a scientifically based climate strategy for 2050 . Economically, it wanted a common European corporate tax of 18 percent, a financial transaction tax, qualified majority voting on tax issues in the Council of Ministers. Sustainable 
farming should be supported through fair prices, and pollution should be taxed. Single use plastics should be banned. Research and development should be strengthened, it opposed geoblocking and upload filters and demanded more cooperation on cyber security. It also proposed a fairer distribution mechanism for migrants.

The Greens naturally focused extensively on climate change with the development of more sustainable technologies and the fight against single use plastics and non-biodegradable plastics. They wanted to promote emissions-free vehicles and investments in public transport, including an express-train network that connects European capitals. Animal protection should be improved and pesticides and glyphosate should be banned. In the area of migration policies, the drivers of migration should be tackled, while people helping migrants should not be criminalized. Refugees should be distributed across EU member states. It also demanded a European minimum salary and unemployment insurance.

The ADR campaigned for a Europe of the nations, where asylum, family and societal questions and tax policy are national competences. It opposed the enlargement to Turkey and wanted Luxembourgish to become an official language of the EU. The Maastricht criteria have to be respected and the monetary union cannot become a transfer union. Defence cooperation is desirable, but without a European army. It also opposed the introduction of filters and 'censorship' on the internet.

Finally, the Pirate Party followed the European election programme, but highlighted ten priorities: pro-Europeannes, the same rights and opportunities for everyone in Europe, a European minimum wage, digitalization and democratization of the EU through the direct election of the Commission President and referendums. It also demanded healthier food, to combat climate change and emphasize renewable resources. Finally, the EU should focus on peace, be more transparent and improve the protection of animals.

Overall, we can see that the centrist parties share certain positions, for example on the distribution of migrants. However, the CSV does not support the idea of a European minimum wage and the environmental dimension is of course particularly strong in the Green party programme. The ADR is the only party that goes clearly into a different dimension, focusing less on policies and more on the distribution of competences between the EU and member states as well as more restrictive migration policies.

\subsubsection{Campaign Issues}

The 2019 European elections were the second time that the so-called Spitzenkandidaten Process was used. The European Parliament's goal was that the lead candidate of the party that won the elections would become President of the European Commission. Not all European parties nominated lead candidates, but most of the parties with a chance of forming a majority in parliament had either appointed a Spitzenkandidat (e.g. EPP, PES), or a team of lead candidates (e.g. the Greens/European Free Alliance, Renew Europe). The Luxembourgish media strongly supported the idea that a Spitzenkandidat should become Commission President, and when the European Council decided to nominate another candidate, most Luxembourgish parties saw this critically. In a way, this support for the process is unsurprising, as Luxembourg had a successful Spitzenkandidat in the first round in 2014, Jean-Claude Juncker. In addition, the Luxembourgish media follow the German media very closely, and as Germany had several 
Spitzenkandidaten in 2014 and 2019 it is one of the countries where the media strongly support the concept.

However, there is an element of hypocrisy in the disappointment. The campaign was not about the next Commission President. The posters did now show the Spitzenkandidaten, but the national candidates for the European election. The same is true for the manifestos and campaign material that were distributed door-to-door: For all parties it included both the six candidates of the party and the programme of the party, but not the European Spitzenkandidat. The websites of the parties equally focus on the Luxembourgish candidates. This approach makes sense given the electoral system. Voters have two choices: they can either vote for a party, or they can give their votes to their preferred candidates (who can be from different parties). This second method has gained importance over time. The number of people who vote for candidates rather than parties rose steadily to over 50 percent in the 2004 national elections (Dumont et al. 2011), but fell for the first time in 2013 to 41 percent (Schmit 2018). In addition, the proportion of voters who use inter-party panachage (i.e. who support candidates from different parties) doubled between 1979 and 2009 to 36.5 percent (Schmit 2018). For parties, it is thus important that voters get to know their candidates as much as possible before the elections, as over 40 percent of voters are likely to vote for people they know, trust and like. The pan-European Spitzenkandidaten, however, are not on the list and therefore cannot attract any votes for the party.

Only two parties explicitly used a European party programme rather than a national party programme for the elections. The Pirates and the new pro-European movement Volt used European programmes, also this is not clearly visible to the voter from some of the Pirate's brochures.

On the whole, the European elections in Luxembourg were thus primarily a contest between national parties and their priorities. However, as the analysis of the manifestos showed, the parties did focus on European policies rather than national issues. It is clear that the migration crisis, in particular, was an important topic with parties positioning themselves either in favour of a distribution of migrants and Europe-wide solidarity or in favour of a restrictive migration policy. The Eurozone crisis still had some impact, in the sense that debates about a European minimum wage or unemployment insurance are related to the austerity policies of the Eurozone crisis. Brexit, on the other hand, played almost no role.

\subsection{Turnout and Results}

84.24 percent of voters took part in the 2019 elections, which is somewhat lower than in the previous European election. One explanation for this could be voting fatigue, as Luxembourg held municipal elections in 2017, national elections in autumn 2018 and European elections in spring 2019. Ten parties competed in the elections, including two new parties, the pro-European Volt and the far right The Conservatives.

On the whole, the elections were marked by the strong decline of the CSV, which lost over 16 percent compared to 2014. In addition, the two parties of the far left, The Left and the Communist Party suffered some losses. The nationalist and anti-European The Conservatives only gained 0.53 percent of the vote, and the euro-critical ADR gained 2.5 percent. All three governing parties also gained votes, but the LSAP only grew very slightly, especially considering that its previous result from 2014 had been a low point. The Greens benefitted from 
the increasing salience of climate change and environmental topics. The greatest winner was the DP, which not only gained over six percent, but also won a second seat at the expense of the CSV, which lost a seat. Overall, the CSV and the DP both won two seats, and the Greens and

the

LSAP

won

one.

Table 3: the Results of the 2019 European Election

\begin{tabular}{|l|l|l|l|l|l|l|}
\hline Party & $\mathbf{\%}$ & $+/-$ & Seats & $+/-$ & $\begin{array}{l}\text { No. } \\
\text { Female } \\
\text { MEPs }\end{array}$ & $\begin{array}{l}\text { \% } \\
\text { female } \\
\text { MEPs }\end{array}$ \\
\hline Democratic Party & 21.43 & +6.66 & 2 & +1 & 1 & 50 \\
\hline Christian Social People's Party & 21.10 & -16.56 & 2 & -1 & 1 & 50 \\
\hline The Greens & 18.91 & +3.90 & 1 & 0 & 1 & 100 \\
\hline Socialist Workers' Party & 12.21 & +0.48 & 1 & 0 & 0 & 0 \\
\hline Alternative Democratic Reform Party & 10.03 & +2.50 & 0 & 0 & & \\
\hline Pirate Party Luxembourg & 7.70 & +3.47 & 0 & 0 & & \\
\hline The Left & 4.84 & -0.92 & 0 & 0 & & \\
\hline Volt Europa & 2.11 & +2.11 & 0 & 0 & & \\
\hline Communist Party of Luxembourg & 1.14 & -0.35 & 0 & 0 & & \\
\hline The Conservatives & 0.53 & +0.53 & 0 & 0 & & \\
\hline Total & 100 & & 6 & & & \\
\hline
\end{tabular}

\subsection{Comparison with Previous European and National Elections}

Table 4: European Election Results (in per cent)

\begin{tabular}{|c|c|c|c|c|c|c|c|c|c|}
\hline & 1979 & 1984 & 1989 & 1994 & 1999 & 2004 & 2009 & 2014 & 2019 \\
\hline CSV & 36.13 & 34.90 & 34.87 & 31.50 & 31.67 & 37.13 & 31.36 & 37.66 & 21.10 \\
\hline LSAP & 21.65 & 29.93 & 25.45 & 24.80 & 23.58 & 22.09 & 19.48 & 11.73 & 12.21 \\
\hline DP & 28.13 & 22.07 & 19.95 & 18.83 & 20.46 & 14.87 & 18.66 & 14.77 & 21.43 \\
\hline Déi Gréng & & 6.08 & 10.46 & 10.93 & 10.70 & 15.02 & 16.83 & 15.01 & 18.91 \\
\hline ADR & & & & 6.95 & 8.99 & 8.03 & 7.39 & 7.53 & 10.03 \\
\hline KPL & 5.01 & 4.08 & 4.71 & 1.63 & & 1.17 & 1.54 & 1.49 & 1.14 \\
\hline Déi Lénk & & & & & 2.77 & 1.69 & 3.37 & 5.76 & 4.84 \\
\hline SDP & 7.00 & & & & & & & & \\
\hline Piraten & & & & & & & & 4.23 & 7.70 \\
\hline Volt Europa & & & & & & & & & 2.11 \\
\hline Déi Konservativ & & & & & & & & & 0.53 \\
\hline Others & 2.08 & 2.94 & 4.56 & 4.43 & 1.83 & 0.00 & 1.38 & 1.82 & 0.00 \\
\hline
\end{tabular}

Table 5: Turnout in the European and National Elections in Luxembourg (in per cent)

\begin{tabular}{|c|c|c|c|c|c|c|c|c|c|c|c|}
\hline & 1979 & 1984 & 1989 & 1994 & 1999 & 2004 & 2009 & 2013 & 2014 & 2018 & 2019 \\
\hline National elections* & 89.3 & 88.8 & 88.81 & 87.39 & 86.51 & 91.92 & 90.81 & 91.32 & & 89.66 & \\
\hline European elections** & 88.91 & 88.79 & 87.39 & 88.55 & 87.27 & 91.35 & 90.76 & & 85.55 & & 84.24 \\
\hline
\end{tabular}

*Source: 1979, 1984: Dumont, Kies and Poirier (2016); 1989, 1994: official election report; 1999-2018: https://statistiques.public.lu/stat/TableViewer/tableView.aspx 


\section{The 2019 European Election: Theoretical Analysis}

Four questions merit particular attention: Firstly, European elections have often been described as second-order elections, i.e. elections whose outcome is determined by national politics rather than by European politics. However, in recent years the impact of European integration and European policy-making on citizens has become much more visible than in previous decades. The migration crisis and the Eurozone crisis, in particular, have brought to the fore two issues that undeniably have a European dimension, and that dimension has been extensively discussed in the media (Högenauer and Howarth 2019). In addition, the European Parliament introduced the Spitzenkandidaten procedure in 2014 with the goal of increasing the party-political competition and the political impact of the outcome of the European elections. Both of these developments might have led to a shifting perception of the importance of European elections. It is therefore worth analysing whether European Parliament elections can (still) be considered second-order elections today. Secondly, eurosceptic parties were on the rise in the past European elections and in many national elections. Is this trend also observable in this particular case? Also, with a changing party landscape often comes a high degree of electoral volatility. Can this trend also be observed in Luxembourg? If so, what drives it? Thirdly, Luxembourg has long struggled with gender equality in politics and has recently introduced quotas in order to tackle the issue. To what extent have these quotas worked, and how does the electoral system impact gender equality?

\subsection{Second-Order Elections and European Salience Theory}

As Viola (2016) illustrates, even before the first direct elections to the European Parliament many politicians voice concerns that elections to a relatively powerless and unknown European assembly would be marred by low turnout and a focus on domestic issues and the performance of the national government. After the first election, Reif and Schmitt (1980) confirmed these concerns. They argued that there were two types of elections: 'principal' elections with high stakes (e.g. elections to the national legislature or presidential elections) and secondary elections, 'second-order elections', like local elections, by-elections and now the European elections, that were perceived by voters as having a limited importance. As a result, these elections were seen to have five distinctive features: Firstly, as voters perceive the stakes as low, mobilization is weaker, resulting in a low turnout. This low mobilization is problematic in so far as low turnout is an indication that voters feel that the election has not much of an impact (Franklin 2014). Secondly, the focus lies on national rather than European issues. This can be due to disinterest on the part of the voters, the parties or both (Ferrara and Weishaupt 2004). Thirdly, governing parties lose support compared to national elections, as discontented voters use the opportunity to punish the government (Norris 1997). Fourthly, small parties, protest parties and radical parties attract a larger share of votes, as voters do not perceive the election as having major consequences. Finally, the timing of the election matters, with governing parties performing better when the EP election follows closely a national election and are they are riding on the same wave of support and less good when it is happening towards the national mid-term or the end of term, when voters may feel dissatisfied (Reif 1984; Oppenhuis, van der Eijk and Franklin 1996).

By contrast, European salience theory argues that European integration is becoming a more salient dimension over time (de Vries 2007; de Vries, van der Brug, and van Egmond 2011; Hobolt and Spoon 2012). It is supported by studies that show that Europe matters in EU elections (e.g. Hix and Marsh 2007; 2011). As Viola (2016) argues, this has led to the 
emergence of three hypotheses: that Green parties, extreme parties on the right or left and antiEuropean parties fare better in European elections than in the previous national elections. Finally, Ferrara and Weishaupt (2004) show that parties that have a clear stance on Europe perform better than those that are internally divided on European integration and that therefore fail to provide a coherent vision.

\subsection{The Second-Order Voting Theory and the European Salience Theory in the case of Luxembourg}

As voting is mandatory in Luxembourg, the fist criteria for a second-order election - low turnout - is of course not fulfilled. In addition, the first seven European Parliament elections took place on the same day as the national legislative elections, which means that the turnout for both elections is very similar. On five occasions, the turnout was slightly lower than for the national election, and on two it was slightly higher. However, after the fall of the Juncker government in 2013, the elections no longer coincided and the national election now precedes the European election. Interestingly, while the turnout for European elections is still high at around 85 percent, it was on both occasions around five or six percent lower compared to the previous national elections, which does suggest that voters attach less importance to European elections (cf. Table 5, above).

There is also no strong evidence for the second-order theory in terms of how voters vote in European elections compared to the most recent national election. The CSV was in government from 1979 until 2013, but only lost votes on two occasions, and only once noticeably with over six percent. By contrast, its biggest ever loss was in 2019 with over minus 7 percent compared to the previous national election, when it had already been in opposition since 2013. Other governing parties also experienced mixed dynamics: The DP gained over six percent in 1979 after it had been in government and again in 2019, and the Green gained votes twice in 2014 and 2019 despite being in government. The LSAP, by contrast, lost votes in 1979, 2014 and 2019 as a governing party.

The results also fail to support the hypotheses of second-order election theory and European salience theory in term of the performance of radical, populist and anti-European parties. The anti-European and extreme right wing Déi Konservativ gained only around a quarter of a percent of votes in the 2019 European election, which is lower than their performance in the national election. On the left, the euro-critical Déi Lénk and the eurosceptic Communist Party have a mixed record of minor gains and losses. The euro-critical ADR always performed better nationally until 2009, but in the last two elections performed better in European elections. The only expectation that is strongly supported by evidence is hypothesis of European salience theory that Green parties do well in European elections: the Luxembourgish Greens consistently performed better in every single European election compared to the national elections.

Table 6: Electoral Volatility in European Elections compared to National Elections (changes in per cent)

\begin{tabular}{|c|c|c|c|c|c|c|c|c|c|}
\hline & MV79 & MV84 & MV89 & MV94 & MV99 & MV04 & MV09 & MV14 & MV19 \\
\hline CSV & -0.26 & -1.75 & 2.45 & 1.19 & 1.58 & 1.00 & -6.68 & 3.98 & -7.21 \\
\hline LSAP & -0.86 & -1.86 & -0.76 & -0.59 & 1.29 & -1.28 & -2.08 & -8.55 & -5.39 \\
\hline DP & 6.25 & 1.71 & 2.76 & -0.45 & -1.89 & -1.19 & 3.67 & -3.48 & 4.52 \\
\hline Déi Gréng & 0.00 & 1.86 & 1.90 & 1.02 & 1.62 & 3.44 & 5.11 & 4.88 & 3.79 \\
\hline ADR & 0.00 & 0.00 & $-7.92 *$ & -2.08 & -2.32 & -1.92 & -0.75 & 0.89 & 1.75 \\
\hline
\end{tabular}




\begin{tabular}{|l|l|l|l|l|l|l|l|l|l|}
\hline KPL & 0.15 & -0.30 & 0.31 & -0.72 & 0.00 & 0.26 & 0.07 & -0.15 & -0.13 \\
\hline Déi Lénk & 0.00 & 0.00 & 0.00 & 0.00 & -0.53 & -0.18 & 0.09 & 0.82 & -0.64 \\
\hline SDP & 0.62 & 0.00 & 0.00 & 0.00 & 0.00 & 0.00 & 0.00 & 0.00 & 0.00 \\
\hline Piraten & 0.00 & 0.00 & 0.00 & 0.00 & 0.00 & 0.00 & 0.00 & 1.29 & 1.25 \\
\hline Volt & 0.00 & 0.00 & 0.00 & 0.00 & 0.00 & 0.00 & 0.00 & 0.00 & $\mathbf{2 . 1 1}$ \\
\hline Déi Konservativ & 0.00 & 0.00 & 0.00 & 0.00 & 0.00 & 0.00 & 0.00 & 0.00 & -0.27 \\
\hline
\end{tabular}

There are, however, two arguments in favour of the European elections being second-order elections: Firstly, the European and the national elections took place on the same day from 1979 until 2009, and the results are usually close together. This suggests that both elections follow the same dynamic, rather than separate national and European dynamics. Secondly, until after the 2004 election, parties often fielded prominent figures in domestic politics as European candidates, who would attract a large number of personal votes, but then did not take office and instead passed on their seats to less popular candidates. The 2004 elections are a good example of this, as only two of the Luxembourgish MEPs were elected directly, whereas four were merely replacements for more popular domestic politicians who did not take up their seats. One can assume that the voters knew that those candidates did not intend to become MEPs, as they included the prime minister who was simultaneously campaigning to remain prime minister. On the whole, if parties are willing to fill their lists with candidates from domestic politics who do not intend to go into European politics, and if voters are happy to express strong support for these candidates, it is an indication that the election is not principally about Europe for either the political elite or the voter. The electoral rules have now been changed to avoid this issue, so that the elections are losing some of their second-order character now that the focus is on candidates who want to become MEPs.

\subsection{The Fate of Eurosceptic and Populist Parties}

Luxembourg has four parties that can be seen as ranging from euro-critical to euro-sceptical or anti-European. However, there is no electoral support for strong anti-European sentiments or parties who wish to roll back European integration, and none of these parties has ever won a seat in the European Parliament. As mentioned previously, the new anti-European and extreme right Déi Konservativ only gained 0.27 percent of the vote in their first European elections in 2019. The populist and euro-critical ADR gained about 1.5 percent in 2019, but this is mostly due to the fact that 2014 was a low point for the party. If placed in a wider context, the 2019 result is only the fourth best result of the party in seven elections. The eurosceptic Communist Party experienced strong electoral decline in the 1990s and has been below two percent ever since. It has been replaced by the younger Déi Lénk, which now polls around 5.5 percent. On the whole, there has been no clear trend towards eurosceptic parties in the past decade. It is also worth mentioning that the new pro-European Volt party managed to get over 2 percent in its first election.

\subsection{Electoral Volatility}

Despite the fact that there is no clear rise in populist or extreme parties, Luxembourg has experienced increased electoral volatility in the most recent elections. This is due to the emergence of successful new parties, such as the Pirate Party, but also to the crisis of the LSAP 
and, especially, the CSV. These two established parties are perceived to be out of touch with younger voters, in particular. In the case of the CSV, the inability of the long-time government party to define an opposition role for itself and to delineate itself clearly from the other centrist parties has led to a very rapid decline of support since 2018 . The party fell from over 30 percent in opinion polls to a little over 21 percent in the European elections in May 2019. As a result, the party lost a staggering 16.56 percent in the European elections of 2019 compared to the European elections of 2014. It is too early to speak of a trend, though. It is impossible to predict whether the CSV will stagnate at the current level (potentially leading to low volatility), recover its losses after a repositioning (leading to high volatility, but also a 'return to normal' of the party landscape) or a further decline.

\subsection{Gender Issues in Parliamentary Elections}

The statistics of the European Parliament paint a rosy picture with regard to gender equality in Luxembourgish politics. According to the European Parliament, Luxembourgers returned five times perfect gender parity in the past nine elections $(2019,2004,1994,1989,1984)$. Twice two out of six MEPs were women, and twice only one MEP out of six was female. Unsurprisingly, Luxembourg was most of the time above average in terms of gender equality.

Figure 3: The Gender of Luxembourgish MEPs

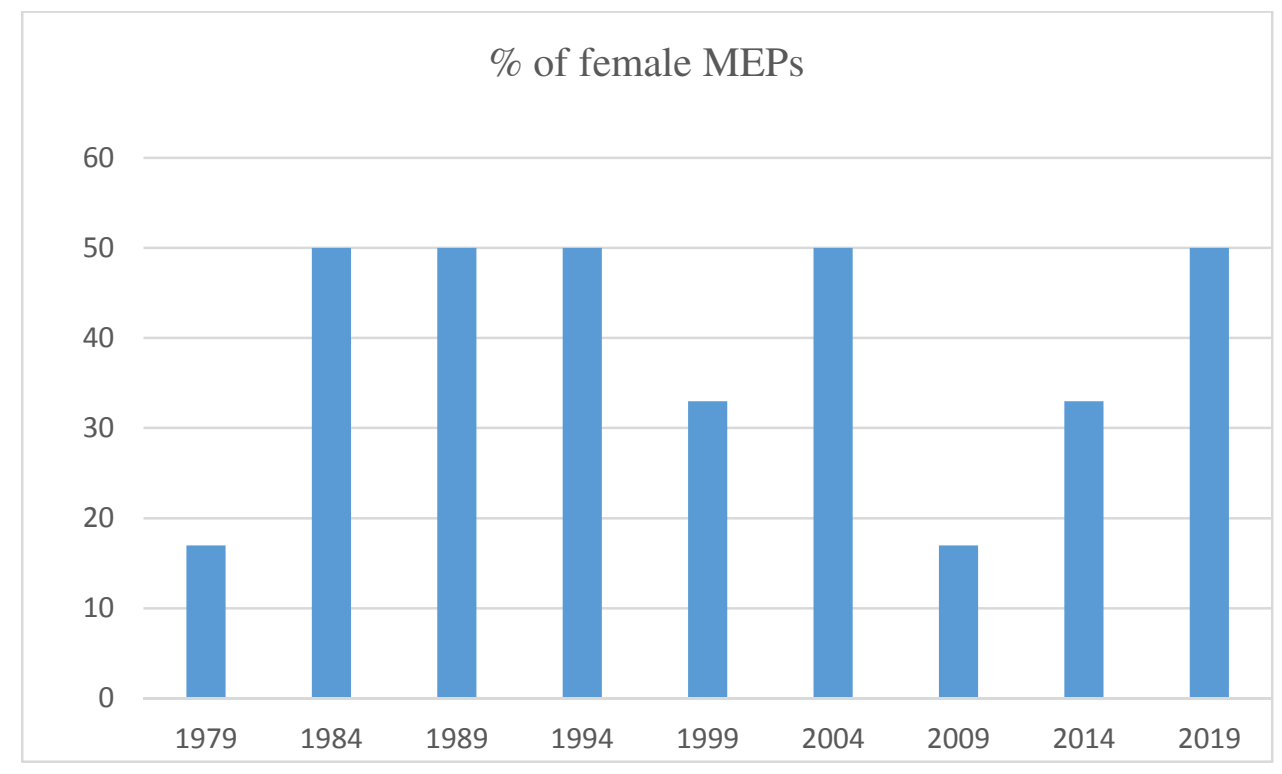

https://election-results.eu/mep-gender-balance/2019-2024/

However, these official statistics are somewhat misleading. How many women are elected and how many women become MEPs are two different questions, and the answers can diverge considerably. The EP statistics only capture the number of female MEPs, not who people voted for. In reality, the Luxembourgish electoral system with its open lists tends to put women at a disadvantage, as those voters who vote for individual candidates tend to favour men. 
As explained previously, it was common practice for prominent national politicians to also run in the European elections until the early 2000s, and to then not take up their seats (Dumont, Kies and Poirier 2016). As a result, there is limited overlap between the six people who could have become MEPs and the six people who did become MEPs in certain years. The most recent example of misleading gender parity prior to 2019 was the 2004 election. Three MEPs were men and three were women, but, in reality, only one single women (Lydie Polfer, DP) was elected directly to the European Parliament. The other five MEPs would have been men. However, four of those men did not take up their seats (including Prime Minister Jean-Claude Juncker) and were replaced with two other men and two women. In fact, none of the three CSV MEPs were among the three top CSV candidates.

Women do not fare well in Luxembourgish national elections either. In 1994, 1999 and 2004 only 20 percent of MPs were women. In 2009, one quarter were women and in 201314 out of 16 (slightly less than a quarter) were women (http://fraendag.lu/fr/errungenschaften/). Of course, one of the key questions is whether this disparity is due to a supply problem (not enough female candidates) or a demand problem (voters do not vote for them). Until 2013, one could argue that the low representation of women was due to both: In 2013 only 34.44 percent of candidates were women, but of course an even smaller proportion was elected (http://archive.ipu.org/parline-f/reports/1191.htm\#last). In the end, after various male MPs were replaced, for example due to the formation of the government, 19 women were in parliament (https://paperjam.lu/article/news-moins-de-femmes-et-peu-de-jeunes-a-lachambre).

Because of the poor representation of women, quotas for candidates were introduced. The law of 15 December 2016 states that parties have to include at least 40 percent of candidates from either gender on their list if they wish to obtain the full party funding. For European elections, parties have to present three male and three female candidates, if they want to obtain the full funding.

Unfortunately, the introduction of quotas did not produce the intended effect. Around 46 percent of candidates in the 2018 national election were indeed women, but only 12 out of 60 successful candidates were female. In other countries, this might have been due to parties giving men the prime spots on the list, but as Luxembourgish lists are alphabetical, the lists cannot be blamed for the outcome. Rather, it seems that the electoral support for women was low. After the formation of the government and the replacement of MPs there were 15 women in parliament (25 percent).

As a result, the representation of women was an issue in the 2019 elections. In accordance with the new rules on party financing, eight out of ten parties included 50 percent of female candidates. Only the Pirate Party and the extreme right The Conservatives presented lists that included four men and two women. As a result, out of 60 candidates from 10 parties, 32 were men and 28 were women. In addition, the ministry supported a 'vote 50-50' campaign to make voters more aware of the problem and encourage them to distribute their votes more evenly (https://www.50-50.lu/). In this case, the campaign and the quotas paid off, as the election did return 50 percent of female MEPs.

\section{Conclusion}


To conclude, the European elections in Luxembourg have changed over time. Firstly, the fact that they no longer take place on the same day as national elections has led to a lower electoral turnout, despite the fact that mandatory voting means that the turnout is still around 85 percent. At the same time, this separation of elections has reduced the second-order nature of European elections and increased to focus on European issues. A reform in 2008, whereby party lists were reduced to six candidates, also contributed to this trend, as party now field more 'serious' candidates with an interest in becoming MEPs rather than prominent domestic politicians who catch votes and then hand their seat to a replacement.

Secondly, unlike many other European countries, Luxembourg has not experienced a surge in Eurosceptic or populist parties. The truly anti-European parties are extremely small, most big parties are pro-European and the two euro-critical parties (Déi Lénk and the ADR) demand reforms rather than an abolition of the EU or the Euro. Despite the absence of a strong populist or Eurosceptic movement, electoral volatility has increased, as support for the CSV and the LSAP has eroded.

Thirdly, official statistics on Luxembourgish MEPs suggest that Luxembourg is doing particularly well with regard to the representation of women in politics, having achieved a parity of men and women several times. However, these statistics are to some extent distorted by the number of 'replacement' MEPs that entered the European Parliament until 2004. National elections show that the open list system does make it harder for women to enter parliaments. Even the introduction of quotas could not immediately change this, as almost half the candidates for the national election of 2018 were women, but only 12/60 elected MPs were female - even fewer than in the previous term. The quotas worked better for the European elections of 2019 in conjunction with a campaign to encourage voters to consider female candidates.

Finally, the campaigns show that the Spitzenkandidaten system is not fully implemented in practice. While many Luxembourgish parties profess their loyalty to the system, posters and leaflets are very much geared towards the national candidates and programmes. Few parties try to highlight their ties to a European party group or present their demands as European demands.

\section{References}

de Vries C. E., W. van der Brug, and M.H. van Egmond. 2011. "Individual and Contextual Variation in EU Issue Voting: The Role of Political Information." Electoral Studies 30(1): 1628.

de Vries, C. E. 2007. "Sleeping Giant: Fact or Fairytale? Examining the Impact of European Integration on National Elections in Denmark and the Netherlands." European Union Politics 8(3): 363-85.

Dumont, P., F. Fehlen, R. Kies, and P. Poirier. 2007. Le référendum sur le Traité établissant une Constitution pour l'Europe, Rapport élaboré pour la Chambre des Députés STADE - Études sociologiques et politiques sur le Luxembourg Université du Luxembourg. Luxembourg.

Dumont, P., R. Kies, and P. Poirier. 2016. "Luxembourg." In: Routledge Handbook of European Elections, edited by D. Viola, 189-210. Abingdon: Routledge. 
Dumont, P., R. Kies, A. Spreitzer, M. Bozinis, and P. Poirier. 2011. Les élections législatives et européennes de 2009 au Grand-Duché de Luxembourg. Synthèse du rapport élaboré pour la Chambre des Députés. Luxembourg : Service Central des Imprimés de l'Etat.

Eurobarometer 11 (June 1979)

Eurobarometer 22 (October 1984)

Eurobarometer 22 (October 1984)

Eurobarometer 31 (March 1989)

Eurobarometer 41 (March 1994)

Eurobarometer 51 (July 1999)

Eurobarometer 61 (May 2004)

Eurobarometer 71 (June 2009)

Eurobarometer 80 (November 2013)

Eurobarometer 89 (March 2018)

Eurobarometer 90 (November 2018)

Ferrara, F., and J.T. Weishaupt. 2004. "Get Your Act Together: Party Performance in European Parliament Elections.” European Union Politics 5(3): 283-306.

Flickinger, R. S., and D.T. Studlar. 2007. "One Europe, Many Electorates? Models of Turnout in European Parliament Elections after 2004." Comparative Political Studies 40(4): 383-404.

Franklin, M. N. 2014. "Why Vote at an Election with No Apparent Purpose? Voter Turnout at Elections to the European Parliament." European Political Analysis (April): 1-12.

Hix, S., and M. Marsh. 2007. "Punishment or Protest? Understanding European Parliament Elections.” Journal of Politics 69(2): 495-510.

Hix, S., and M. Marsh. 2011. "Second-Order Effects plus Pan-European Political Wings: An Analysis of European Parliament Elections across Time.” Electoral Studies 30: 4-15.

Hobolt, S. B., and J.-J. Spoon. 2012. "Motivating the European Voter: Parties, Issues, and Campaigns in European Parliament Elections." European Journal of Political Research 51: 701-27.

Harmsen R. and Högenauer A.L. (2019). "Luxembourg in the European Union." In: Encyclopedia of European Union Politics. Oxford: Oxford University Press.

Högenauer, A.L., and D. Howarth. 2019. „The democratic deficit and European Central Bank crisis monetary policies." Maastricht Journal of European and Comparative Law 26(1): 82-94.

http://archive.ipu.org/parline-f/reports/1191.htm\#last 


\section{http://fraendag.lu/fr/errungenschaften/}

\section{https://csv.lu/eis-partei/presentatioun-partei/).}

https://election-results.eu/mep-gender-balance/2019-2024/

https://paperjam.lu/article/news-moins-de-femmes-et-peu-de-jeunes-a-la-chambre

https://statistiques.public.lu/en/index.html

https://www.50-50.1u/

Loi du 15 décembre 2016 portant 1 . modification du Code du travail; 2. modification de l'article 2 de la loi modifiée du 21 décembre 2007 portant réglementation du financement des partis politiques . Journal officiel du Grand-Duché de Luxembourg, A - $\mathrm{N}^{\circ}$ 264, 21 December 2016, p. 4670

Norris, P. 1997. "Second-Order Elections Revisited" European Journal of Political Research 30(1): 109-14.

Oppenhuis, E., C. van der Eijk, and M.N. Franklin. 1996. “The Party Context: Outcomes”, in Choosing Europe? The European Electorate and National Politics in the Face of Union, edited by C. van der Eijk, and M. N. Franklin, 287-306. Ann Arbor: University of Michigan Press.

Reif, K. H. 1984. "National Electoral Cycles and European Elections 1979 and 1984"." Electoral Studies 3(3); 244-255.

Reif, K. H., and H. Schmitt. 1980. "Nine Second-Order National Elections - A Conceptual Framework for the Analysis of European Election Results." European Journal of Political Research 8(1): 3-44.

Schmit, L. 2018. Der Trend geht zum „Rondel schwäerzen“. Reporter, 28/06/2018.

Viola D. 2016. European Parliament Elections Theories. In: Routledge Handbook of European Elections, edited by D. Viola, 39-48. Abingdon, Routledge.

Volkens, A., W. Krause, P. Lehmann, T. Matthieß, N. Merz, S. Regel, B. Weßels. 2018. The Manifesto Data Collection. Manifesto Project (MRG/CMP/MARPOR). Version 2018b. Berlin: Wissenschaftszentrum Berlin für Sozialforschung (WZB). https://doi.org/10.25522/manifesto.mpds.2018b 